\title{
Consumer attitudes towards healthy and organic food in the Kurdistan region of Iraq
}

\section{Bayad Jamal Ali ${ }^{*}$}

${ }^{a}$ Department of Business Administration, Komar University of Science and Technology, Sulaimani City, Kurdistan Region, Iraq

\section{H R O N I C L E}

\section{Article history:}

Received: December 12, 2020

Received in revised format:

December 292020

Accepted: February 21, 2021

Available online:

February 21, 2021

Keywords:

Organic food product

Consumer behavior

Purchasing decision

\section{A B S T R A C T}

There has been increasing awareness of the benefits of healthy and organic food products as more knowledge has been gained on their effects on health, environment, social convenience and sustainable development. Acquiring insight into consumer attitudes is essential for the industry to grow. Compared with the rest of the world, the Kurdistan region of Iraq is still in the early stages of understanding the importance of healthy and organic food products. The study aim was to investigate the attitudes of Kurdish consumers concerning healthy and organic food. I administered an online survey to 452 respondents, and their responses were analysed by using descriptive statistics and performing correlation, linear regression and factor analysis. The findings indicated that health concerns were the main reason for healthy and organic food consumption. I also found that quality and taste were important factors in purchasing decisions and that consumers were willing to pay a premium price if these foods were available. However, there was a general lack of concern about food production effects on the environment and animal welfare. This research provides a new insight into the attitudes of Kurdish consumers in Iraq towards healthy and organic food. This population has not been covered before, which in turn will add to the literature on this subject.

(C) 2021 by the authors; licensee Growing Science, Canada

\section{Introduction}

There has been increasing demand for organic food products by consumers as awareness has increased concerning the quality, safety, animal welfare and environmental benefits as well as of the direct effects on personal health, lifestyle and social convenience (Oroian et al., 2017). The organic food industry has become a niche industry because of increasing demand (Aygen, 2012; Essoussi \& Zahaf, 2009) as the consumer perception of food has begun to focus on issues other than simply satisfying hunger (Annunziata \& Pascale, 2009). To meet this shifting consumer demand, the main providers of organic food need more information to better understand consumer attitudes about these products (Schleenbecker \& Hamm, 2013). The quality attributes of food and nutritional value have become factors in consumers' consideration of food choices. Food habits and sociodemographic factors have important roles in shaping consumer acceptance (Lähteenmäki, 2013; Fernqvist \& Ekelund, 2014) and include the origin of the foods consumers purchase (Perito et al., 2019; Menapace et al., 2011; Van der Lans et al., 2001), access to information and trust in food certification (Hobbs \& Goddard, 2015; Russo \& Simeone, 2017), transparency (Peschel \& Aschemann-Witzel, 2020), price range (Asioli et al., 2014; Lusk \& Briggeman, 2009; Steenhuis et al., 2011; Defrancesco et al., 2017; Nait Mohand et al., 2017) and perception of the health benefits and safety of food products (De Pelsmacker et al., 2003), (Boutouis et al., 2018). Therefore, food production objectives involve more than addressing food security and must also satisfy consumer preferences and needs by providing products with functional attributes (Hempel \& Hamm, 2016) and quality features (Defrancesco et al., 2017; Canavari \& Coderoni, 2020). Many studies around the world have investigated attitudes and perceptions of consumers in Kurdistan region of Iraq in general (Ali, 2020; Demir et al., 2020; Ali, 2021), and of consumer perception toward health and organic food products as will be discussed in the literature review, but only a few studies have addressed this topic in Iraq in general and the Kurdistan region in particular. Hasan et al. (2019) studied consumer perceptions of canned agri-food products in Sulaimani City, whereas Ahmed and Khan (2020) studied * Corresponding author. Tel.: +9647701520089

E-mail address: bayad.jamal@komar.edu.iq (B.J. Ali) 
market segmentation of the diet nutrition supply for new entrepreneurs in a case study of the Kurdistan region of Iraq. To the best of our knowledge, these are the only papers on this comprehensive topic. Therefore, the study aim was to investigate the attitudes of Kurdish consumers concerning healthy and organic food with the long-term goal of encouraging consumers to increase their consumption of healthy and organic foods.

\section{Method}

Potential respondents were contacted by e-mail and social media platforms (e.g. Facebook) and invited to participate in an online survey about consumption of healthy and organic foods. The individuals who were willing to participate were sent a link to the research survey. In total, 452 individuals participated in the survey, which was conducted during the second half of 2020. The questionnaire was distributed in the Kurdish language. Simple random sampling was used, the reliability of the questionnaire was tested by using Cronbach's alpha and the validity of the questionnaire was tested by performing correlation analysis. The survey responses were analysed by descriptive statistics and correlation, linear regression and factor analysis to arrive at final conclusions using likert rating scale. The analysis was performed using the SPSS data analysis package and the Amos statistical module 21.0 (IBM SPSS Statistics for Windows, Version 21.0., IBM Corp., Armonk, NY).

\section{Results}

The gender distribution of the participants in the study showed that out of 452 participants, 324 were male (71.7\%) and 128 were female $(28.3 \%)$. In the total sample, a majority $(55.3 \%)$ had bachelor degrees, $27.9 \%$ had higher education degrees, $9.3 \%$ had diploma degrees and $0.4 \%$ had less than a high-school education. The age distribution of the participants was as follows: $41.1 \%$ were $31-50,28.3 \%$ were $26-30,27.4 \%$ were $18-25,2.8 \%$ were $>50$ and $0.40 \%$ were $<18$ years old. The monthly income distribution of the respondents showed that $53.1 \%$ made $<1000$ USD, 19.4\% made 1000-1500 USD, 12.3\% made 1051-2000 USD, 8.6\% made $>2500$ USD and 6.6\% made 2001-2500 USD. To the question of 'How healthy do you think your food habits are?', $46.5 \%$ responded that they had moderately healthy food habits; $37.2 \%$ said that they had healthy food habits; $10.1 \%$ said that they had very healthy food habits; $6.2 \%$ said that they did not have healthy food habits. To the question of 'What do you consider in buying a food product?', $41.6 \%$ of the participants responded that they considered the freshness of a food product, $29.2 \%$ considered whether or not the food was organic, $11.5 \%$ considered the origin of the food, $9.3 \%$ considered price in buying food product and $8.4 \%$ considered the nutritional value. To the question 'How do you acquire information about a food product?', $44.7 \%$ of the participants acquired information about food from package labels, 38.1\% relied on their own information, $7.5 \%$ acquired information from family and $4.4 \%$ got their information from friends. To the question of 'How much do you think that food is related to a healthy life?', $52.3 \%$ of the respondents answered that food was highly related to a healthy life, $39.8 \%$ answered that it was related to healthy life, $4.4 \%$ answered that it might be related to a healthy life and $3.5 \%$ answered that it was only slightly related to a healthy life. To the question 'What drives your choice in buying a food product?', $57.5 \%$ of the respondents were driven by quality and $2.2 \%$ were driven by price. Thus, price was not the primary factor in choosing to buy a food product.

Additionally, $23.5 \%$ of the participants were driven by taste, $9.7 \%$ were driven by the organic characteristic and $7.1 \%$ were driven by nutritional content. To the question of 'What do you consider as healthy food?', $61.1 \%$ mentioned fruits and vegetables; $19.9 \%$ mentioned fish; $7.5 \%$ mentioned nuts and cereals; $7.1 \%$ mentioned organic meat and meat products and $4.4 \%$ mentioned dairy products. To the question of 'Why do you think we should eat healthy food?', $68.6 \%$ answered that it led to a healthy life, $14.2 \%$ answered that it helped them look fit and good, $10.2 \%$ answered that it helped avoid diseases, $4.9 \%$ answered that it would contribute to living a long life and $2.2 \%$ did not think about eating healthy food. To the question of 'What do you consider when buying organic products?', $40.3 \%$ of the respondents were concerned about the health attributes, $31.9 \%$ cared about the origin of the product, $19.8 \%$ were concerned about the use of pesticides, $4.9 \%$ were concerned about the environment and 3.1\% were concerned about animal welfare. To the question of 'How much more would you spend to buy healthy food?', $37.6 \%$ of the respondents would spend $20 \%-30 \%$ more, $25.2 \%$ would spend $10 \%-20 \%$ more, $17.3 \%$ would spend $30 \%-40 \%$ more, $11.5 \%$ would spend $\geq 50 \%$ more and $8.4 \%$ would spend $40 \%-50 \%$ more. In assessing the overall satisfaction with the availability of healthy food products in the city, $43.4 \%$ of the respondents expressed neutral satisfaction, $29.2 \%$ were dissatisfied, $10.6 \%$ were satisfied, $14.2 \%$ were highly dissatisfied and $2.6 \%$ were highly satisfied, which indicated that overall, the respondents were dissatisfied with the availability of health food products in the city.

Furthermore, Table 1 presents the overall attitude towards organic food products. Table 2 presents the rotated factor matrix and reliability (Cronbach's alpha) for all questionnaires. Factor loadings of $<0.45$ are considered less good and factor loadings $>0.45$ are considered good. After performing the Varimax Rotation method, factor one comprised four items, factor two comprised three items, factor three comprised two items, factor four comprised three items and factor five comprised three items. The first factor had the highest Cronbach's alpha, indicating which questions and answers had the greatest effect on purchasing healthy and organic foods. The question, 'I put effort and time into purchasing healthy food products' was the best indicator of purchasing healthy and organic foods. 
Table 1

Overall attitude towards organic food products

\begin{tabular}{|c|c|c|c|c|c|c|c|}
\hline \multirow[b]{2}{*}{ Overall attitude towards organic food products } & \multirow{2}{*}{$\begin{array}{c}5 \\
\begin{array}{c}\text { Frequency } \\
\%\end{array}\end{array}$} & \multirow{2}{*}{$\begin{array}{c}4 \\
\begin{array}{c}\text { Frequency } \\
\%\end{array}\end{array}$} & \multirow{2}{*}{$\begin{array}{c}3 \\
\begin{array}{c}\text { Frequency } \\
\%\end{array}\end{array}$} & \multirow{2}{*}{$\begin{array}{c}2 \\
\begin{array}{c}\text { Frequency } \\
\%\end{array}\end{array}$} & \multirow{2}{*}{$\begin{array}{c}1 \\
\begin{array}{c}\text { Frequency } \\
\%\end{array}\end{array}$} & \multicolumn{2}{|c|}{ Severity } \\
\hline & & & & & & Mean & S.D \\
\hline \multirow{2}{*}{$\begin{array}{l}\text { I prefer organic food products because they are } \\
\text { healthy to eat }\end{array}$} & 48 & 112 & 194 & 68 & 30 & \multirow{2}{*}{3.17} & \multirow{2}{*}{1.03} \\
\hline & 10.6 & 24.8 & 42.9 & 15.0 & 6.6 & & \\
\hline \multirow{2}{*}{$\begin{array}{l}\text { I can spend more to buy healthy foods because it } \\
\text { gives value for money }\end{array}$} & 42 & 178 & 180 & 38 & 14 & \multirow{2}{*}{3.43} & \multirow{2}{*}{0.88} \\
\hline & 9.3 & 39.4 & 39.8 & 8.4 & 3.1 & & \\
\hline \multirow{2}{*}{$\begin{array}{l}\text { I put effort and time into purchasing healthy food } \\
\text { products }\end{array}$} & 44 & 216 & 142 & 42 & 8 & \multirow{2}{*}{3.54} & \multirow{2}{*}{0.85} \\
\hline & 9.7 & 47.8 & 31.4 & 9.3 & 1.8 & & \\
\hline \multirow{2}{*}{$\begin{array}{l}\text { I pay attention to advertisements and promotions } \\
\text { offering information about food products }\end{array}$} & 42 & 226 & 136 & 38 & 10 & \multirow{2}{*}{3.55} & \multirow{2}{*}{0.85} \\
\hline & 9.3 & 50.0 & 30.1 & 8.4 & 2.2 & & \\
\hline \multirow{2}{*}{$\begin{array}{l}\text { I believe locally produced food products are } \\
\text { healthier }\end{array}$} & 86 & 180 & 126 & 42 & 18 & \multirow{2}{*}{3.60} & \multirow{2}{*}{1.02} \\
\hline & 19.0 & 39.8 & 27.9 & 9.3 & 4.0 & & \\
\hline \multirow{2}{*}{$\begin{array}{l}\text { I always recommend buying healthy food products } \\
\text { to others }\end{array}$} & 108 & 246 & 80 & 8 & 10 & \multirow{2}{*}{3.96} & \multirow{2}{*}{0.82} \\
\hline & 23.9 & 54.4 & 17.7 & 1.8 & 2.2 & & \\
\hline \multirow{2}{*}{ Total } & 370 & 1158 & 858 & 236 & 90 & \multirow{2}{*}{3.54} & \multirow{2}{*}{0.90} \\
\hline & 13.6 & 42.6 & 31.6 & 8.7 & 3.5 & & \\
\hline
\end{tabular}

Table 2

Factor loading and Cronbach's alpha

\begin{tabular}{|c|c|c|}
\hline Items & Loadings & Cronbach's Alpha \\
\hline Factor on & & \\
\hline Q12 & 0.554 & \multirow{4}{*}{0.678} \\
\hline Q13 & 0.763 & \\
\hline Q14 & 0.716 & \\
\hline Q16 & 0.681 & \\
\hline \multicolumn{3}{|c|}{ Factor two } \\
\hline Q1 & 0.765 & \multirow{3}{*}{0.602} \\
\hline Q4 & 0.416 & \\
\hline Q5 & 0.718 & \\
\hline \multicolumn{3}{|c|}{ Factor three } \\
\hline Q10 & 0.773 & \multirow{2}{*}{0.635} \\
\hline Q11 & 0.695 & \\
\hline \multicolumn{3}{|c|}{ Factor four } \\
\hline Q2 & 0.747 & \multirow{3}{*}{0.528} \\
\hline Q3 & 0.578 & \\
\hline Q9 & 0.547 & \\
\hline \multicolumn{3}{|c|}{ Factor five } \\
\hline Q7 & 0.535 & \multirow{3}{*}{0.539} \\
\hline Q8 & -0.567 & \\
\hline Q15 & 0.572 & \\
\hline \multicolumn{2}{|c|}{ Factor six } & \multirow[b]{2}{*}{-} \\
\hline Q6 & 0.856 & \\
\hline
\end{tabular}

It can be seen in Table 3 that customer attitude showed a strong positive correlation with healthy food because the correlation coefficient was 0.650 , which is $<0.5$.

Table 3

Correlation coefficients for the relationship between customer attitude and healthy food

\begin{tabular}{cccc}
\hline & & Costumer attitude & Healthy food \\
\hline & Pearson Correlation & 1 & $0.650^{* *}$ \\
Costumer attitude & Sig. (2-tailed) & & 0 \\
& $\mathrm{~N}$ & 452 & 452 \\
Healthy food & Pearson Correlation & $0.650^{* *}$ & 1 \\
& Sig. (2-tailed) & 0 & 452 \\
\hline
\end{tabular}

**: Correlation is significant at the 0.01 level (two-tailed)

Table 4 shows the association between customer attitude and healthy food. Moreover, the $\mathrm{R}^{2}$ value shows that $42.2 \%$ of the variance in healthy food could be explained by the customer's attitude.

Table 4

Association between consumer attitude and healthy food

\begin{tabular}{|c|c|c|c|c|c|c|c|}
\hline & \multicolumn{7}{|c|}{ Heainy rood } \\
\hline & B & Std. Error & F-test & Sig. & $\mathrm{R}^{2}$ & T-test & Sig. \\
\hline Constant & 2.381 & 0.157 & 14.921 & 0.000 & 0.422 & 15.182 & 0.00 \\
\hline Customer attitude & 0.169 & 0.044 & & & & 3.863 & 0.00 \\
\hline
\end{tabular}


Finally, there was a statistically significant association between the customer's attitude and healthy food because the T-test gave a value of 3.863 , with a significance value of 0.0 , which is less than the common alpha of 0.01 . Thus, for all additional degrees of customer attitude, the expected number of healthy foods increased by 0.169 on average.

\section{Discussion}

Many studies have examined the main factors affecting consumer decisions about consuming healthy and organic foods. The main reasons consumers give for buying organic food concern health issues (Aygen, 2012; Gil et al., 2000; Meixner et al., 2014). One major trend in the food market is increasing concern about the health aspects of foods (Aschemann-Witzel et al., 2015), and this issue is intertwined with social and personal value (Goetzke et al., 2014). Currently, consumers are more informed about the relationship between food and health because they have acquired more information about the food that they consume (Annunziata \& Pascale, 2009). In addition, a comparison of French non-organic food consumers with organic food consumers showed that there was a difference in their health, with the organic food consumers not being overweight since they had a healthier diet (Kesse-Guyot et al., 2013). Another study (Zanoli \& Naspetti, 2002) showed that Italian consumers understood the link between organic food and health but also placed high importance on food taste in their food selection. The results of this study show that most Kurdish consumers care about their food habits because the majority responded that they had a moderate to healthy food consumption habit. Moreover, Kurdish consumers considered the freshness of the products they buy first, followed by the organic nature of the product, whereas, a study on Belgian consumers (Aertsens et al., 2011) found that health, environment, minimal use of pesticides, taste and quality were factors in consumers' decision making regarding organic food. One study (Bryla, 2016) found that health and the high quality of organic food products were the main purchasing factors for Polish consumers. However, British and Danish consumers prioritized food taste and freshness above health attributes (Wier et al., 2008) and French consumers also generally priorities taste first and health benefits second in their organic food purchasing decisions. but it was surprising that price was not an important factor in their decision considering that the majority of the respondents' monthly incomes were $<1000$ USD. The food packaging label was the most important source of information to the respondents. We also found it interesting to note the high level of awareness by the respondents concerning the effect of food consumption on health and well-being. Additionally, the quality of food products was an important factor in the purchasing decision of consumers as was taste, but the nutritional value was not rated as important. The respondents considered that consumption of fruits and vegetables was the most important factor in maintaining a healthy lifestyle.

Among the factors in consumers' decisions concerning purchasing organic food, environmental concerns were of low priority, as in Sri Lanka (Kapuge, 2016) and Turkey (Aygen, 2012). However, in other countries, environmental concerns were an important factor along with food safety and origin, such as in Italy (Perito et al., 2020), Indonesia (Irianto, 2015), Australia (Pearson et al., 2013), Thailand (Ueasangkomsate \& Santiteerakul, 2016) and (Sangkumchaliang \& Huang, 2012). In the Czech Republic, consumers gave more weight to health benefits than to environmental concerns (Zagata, 2012). Russian consumers prioritized the lack of synthetics and health issues more than environmental concerns as well (Meixner et al., 2014). However, in India, consumers cared about quality and the environment (Basha et al., 2015) as well as the effect of organic food on health (Yadav \& Pathak, 2016).

In studying the ethical attributes of organic food, one study (Zander \& Hamm, 2010) found that animal welfare was the most important. In Norway, animal rights and environmental concerns were the main factors in consumers' purchasing decisions (Honkanen et al., 2006). Another study (Lee \& Yun, 2015) found that hedonic and utilitarian attitudes influence consumer purchasing decisions about organic food. Moreover, the use of industrial fertilizers or pesticides was a crucial factor in determining consumers' concerns in purchasing organic food, and if these concerns were adequately addressed, consumers preferred purchasing organic food rather than conventional food (Basha et al., 2015), (Saba and Messina, 2003), (Lucas et al., 2008). It is important to note that the respondents of Kurdish consumers stated that environmental and animal welfare concerns were not very important, but the health attributes of the product and its origin were important, as Kurdish consumers would prefer local products versus imported products if available (Ali, 2021). Another important factor in organic food consumption is an individual's income because consumers usually have to pay a premium price. Researchers have shown that unlike highincome individuals, low-income individuals tend to consume unhealthy products (Dibsdall et al., 2002), and low-income individuals in Turkey avoided purchasing organic foods entirely (Aygen, 2012). Interestingly, the majority of the respondents of Kurdish consumers were willing to pay a premium price for healthy and organic products. There are also major obstacles in purchasing organic food, such as the premium price relative to conventional food prices (Aygen, 2012; Padel \& Foster, 2005; Aertsens et al., 2011; Bryla, 2016; Irianto, 2015; Yadav \& Pathak, 2016; Magnusson et al., 2001), trust issues in product certification (Van Huylenbroek et al., 2009), lack of awareness (Xie et al., 2015; Stolz et al., 2011) and lack of availability (Aygen, 2012; Xie et al., 2015; Aertsens et al., 2009; Toit \& Crafford, 2013), whereas in Denmark, the lack of availability was overcome by governmental reforms that encouraged organic food consumption (Hjelmar, 2011). However, there are institutional barriers in Iran against buying organic food in addition to low quality, cultural barriers and economic obstacles (Sadati et al., 2010). However, perceptions about premium pricing of organic foods could be shifted when these foods are seen as an investment in human health (Bonti-Ankomah \& Yiridoe, 2006). Consumers in the Kurdistan region of Iraq also found it difficult to acquire these products because of the lack of availability. Health benefits are the main driver for purchasing organic products for consumers in many countries, such as Sri Lanka (Kapuge, 2016), Indonesia (Irianto, 2015), India, (Yadav \& Pathak, 2016), China (Xie et al., 2015) and Thailand (Ueasangkomsate \& Santiteerakul, 2016). However, in Malaysia, 
researchers found an unexpected result in that although health and safety were important factors to consumers, food quality was not (Wee et al., 2014). Another interesting finding was that in Taiwan, purchasing organic food from trusted acquaintances was an important factor to Taiwanese consumers (Teng \& Wang, 2015). Another study (Al-Swidi et al., 2014) found that Pakistani consumers relied on a reference group to guide them in their organic food purchases. Furthermore, there was a positive perception about organic products among the Kurdish consumers, and the majority would recommend and encourage their acquaintances to consume healthy and organic products. In examining consumers in the United Arab Emirates, one study (Muhammad et al., 2016) found that women were less aware of organic products than men. However, in a study (Irianto, 2015) conducted in Indonesia, the results showed that women were more concerned about health and the environment than men, and similar findings were found in Spain (Gil et al., 2000), the United Kingdom (Padel \& Foster, 2005) and France (Kesse-Guyot et al., 2013). Moreover, having children in the household was an important factor that encouraged the purchase of organic food (Aygen, 2012; Dumea \& Andrei, 2012; Xie et al., 2015; Sangkumchaliang \& Huang, 2012).

Several studies have found that organic food consumers are more likely to be educated and older (Kesse-Guyot et al., 2013; Sangkumchaliang \& Huang, 2012; Toit \& Crafford, 2013; Ramesh \& Divya, 2015). However, young respondents and women have shown favorable attitudes toward organic food in Sweden (Magnusson et al., 2001). Overall, the attitudes of Kurdish consumers were positively and strongly correlated with healthy organic food.

\section{Study limitation}

The limitation of this study was that it only covered a sample of the Kurdistan region of Iraq. Therefore, future studies may consider a more comprehensive framework to examine policy formulation, education, awareness, product availability and examine changes in consumer behavior.

\section{Conclusion}

Food security is an increasing challenge in the world today. In addressing this challenge, conventional farming can be seen as a success, but it has negative effects on the ecosystem and environment. Organic farming is a method that reduces the negative effects of conventional farming and could be a useful tool worldwide for improving the environment in the present and sustaining it in the future. However, it will take more time, effort and research to gain the required knowledge about the best way to implement organic farming on a broader scale. The study finds that Kurdish consumers care about their food habits and associated health attributes and they also give high importance to freshness of the food products and their organic nature. It was also found that there is a high level of awareness on the impact of food on health among Kurdish consumers, which resulted in quality of products being the most important factor in their purchasing decision. However, there is a lack of awareness about the environment and animal welfare. An interesting finding is that the majority of Kurdish consumers are willing to pay a premium price to acquire healthy organic food but there is a lack of availability in the market. Developing consumer awareness of the benefits of organic products requires time and the cost associated with providing that information. Moreover, the organic food market needs to grow in order to encourage farmers to enter that market and encourage consumer consumption. Because of the lack of research on the Iraqi market in general and the Kurdistan regional market in particular, this study attempted to provide insights into Kurdish consumers' attitudes toward healthy and organic products. Understanding the significance of consumers' attitudes will help policy makers, market planners, researchers and businesses to expand their perceptions about this field and provide consumers with information, awareness, health benefits, organic food production and consumption as well as to support organic farmers. Moreover, it is imperative that the producers and sellers of organic products have the necessary information about their consumers' preferences so that products can be offered that meet the quality and price expectations of consumers.

\section{References}

Aertsens, J., Mondelaers, K., Verbeke, W., Buysse, J., \& Van Huylenbroeck, G. (2011). The influence of subjective and objective knowledge on attitude, motivations and consumption of organic food. British Food Journal, 113(11).

Ahmed, M. A. (2020). Market segmentation of diet nutrition supply for the new entrepreneurs: Case study in Kurdistan Region of Iraq. Black Sea Journal of Management and Marketing, 1(1), 17-28.

Ali, B. J. (2020). Impact of COVID-19 on consumer buying behavior toward online shopping in Iraq. Economic Studies Journal, 18(42), 267-280.

Ali, B. J. (2021). Assessing (The impact) of advertisement on customer decision making: Evidence from an educational institution. Afak for Sciecnes, 6(1), 425-439.

Ali, B. J. (2021). Impact of Consumer Animosity, Boycott Participation, Boycott Motivation, and Product Judgment on Purchase Readiness or Aversion of Kurdish Consumers in Iraq. Journal of Consumer Affairs, 1-20. https://doi.org/10.1111/joca.12350

Al-Swidi, A., Huque, S. M. R., Hafeez, M. H., \& Shariff, M. N. M. (2014). The role of subjective norms in theory of planned behavior in the context of organic food consumption. British Food Journal.

Annunziata, A., \& Pascale, P. (2009). Consumers' behaviours and attitudes toward healthy food products: The case of Organic and Functional foods (No. 698-2016-47803). 
Aschemann-Witzel, J., De Hooge, I., Amani, P., Bech-Larsen, T., \& Oostindjer, M. (2015). Consumer-related food waste: Causes and potential for action. Sustainability, 7(6), 6457-6477.

Asioli, D., Næs, T., Granli, B. S., \& Lengard Almli, V. (2014). Consumer preferences for iced coffee determined by conjoint analysis: An exploratory study with N orwegian consumers. International journal of food science \& technology, 49(6), $1565-1571$.

Aygen, F. G. (2012). Attitudes and Behavior of Turkish Consumers With Respect to Organic Foods. International Journal of Business and Social Science, 3(18).

Basha, M. B., Mason, C., Shamsudin, M. F., Hussain, H. I., \& Salem, M. A. (2015). Consumers attitude towards organic food. Procedia Economics and Finance, 31, 444-452.

Bonti-Ankomah, S., \& Yiridoe, E. K. (2006). Organic and conventional food: a literature review of the economics of consumer perceptions and preferences. Organic Agriculture Centre of Canada, 59, 1-40.

Boutouis, M. Z., Hammoudi, A., Benhassine, W., \& Perito, M. A. (2018). Uncertainty of food contamination origin and liability rules: Implications for bargaining power. Agribusiness, 34(1), 77-92.

Bryła, P. (2016). Organic food consumption in Poland: Motives and barriers. Appetite, 105, 737-746.

Canavari, M., \& Coderoni, S. (2020). Consumer stated preferences for dairy products with carbon footprint labels in Italy. Agricultural and Food Economics, 8(1), 1-16.

Demir, A., Maroof, L., Khan, N. U. S., \& Ali, B. J. (2020). The role of E-service quality in shaping online meeting platforms: a case study from higher education sector. Journal of Applied Research in Higher Education.

De Pelsmacker, P., Driesen, L., \& Rayp, G. (2003). Are fair trade labels good business? Ethics and coffee buying intentions. Journal of consumer affairs, 39(2), 1-20.

Defrancesco, E., Perito, M. A., Bozzolan, I., Cei, L., \& Stefani, G. (2017). Testing consumers' preferences for environmental attributes of pasta. Insights from an ABR approach. Sustainability, 9(10), 1701.

Dibsdall, L. A., Lambert, N., Bobbin, R. F., \& Frewer, L. J. (2003). Low-income consumers' attitudes and behaviour towards access, availability and motivation to eat fruit and vegetables. Public Health Nutrition, 6(2), 159-168.

Dumea, A. C., \& Andrei, A. G. (2012), "Organic food consumer in Romania", Available at http://mpra.ub.unimuenchen.de/36865/ (accessed on 12 November 2020).

Essoussi, L. H., \& Zahaf, M. (2009). Exploring the decision-making process of Canadian organic food consumers. Qualitative Market Research: An International Journal.

Fernqvist, F., \& Ekelund, L. (2014). Credence and the effect on consumer liking of food-A review. Food Quality and Preference, 32, 340-353.

Gil, J. M., Gracia, A., \& Sanchez, M. (2000). Market segmentation and willingness to pay for organic products in Spain. The International Food and Agribusiness Management Review, 3(2), 207-226.

Goetzke, B., Nitzko, S., \& Spiller, A. (2014). Consumption of organic and functional food. A matter of well-being and health?. Appetite, 77, 96-105.

HASAN, K. J., NEIMA, H. A., ISMAEL, K. S., HARUN, R., \& HAMA SALIH, C. M. (2019). Consumers Perception of Canned Agri-food Products in Sulaymanyah City, Kurdistan Regional Government Iraq. ProEnvironment Promediu, 12(39).

Hempel, C., \& Hamm, U. (2016). Local and/or organic: A study on consumer preferences for organic food and food from different origins. International Journal of Consumer Studies, 40(6), 732-741.

Hjelmar, U. (2011). Consumers' purchase of organic food products. A matter of convenience and reflexive practices. Appetite, 56(2), 336-344.

Hobbs, J. E., \& Goddard, E. (2015). Consumers and trust. Food Policy, 52, 71-74.

Honkanen, P., Verplanken, B., \& Olsen, S. O. (2006). Ethical values and motives driving organic food choice. Journal of Consumer Behaviour: An International Research Review, 5(5), 420-430.

Irianto, H. (2015). Consumers' attitude and intention towards organic food purchase: An extension of theory of planned behavior in gender perspective. International journal of management, economics and social sciences, 4(1), 17-31.

Kapuge, K. D. L. R. (2016). Determinants of organic food buying behavior: Special reference to organic food purchase intention of Sri Lankan customers. Procedia food science, 6, 303-308.

Kesse-Guyot, E., Péneau, S., Mejean, C., de Edelenyi, F. S., Galan, P., Hercberg, S., \& Lairon, D. (2013). Profiles of organic food consumers in a large sample of French adults: results from the Nutrinet-Sante cohort study. PloS one, 8(10), e76998.

Lähteenmäki, L. (2013). Claiming health in food products. Food Quality and Preference, 27(2), 196-201.

Lee, H. J., \& Yun, Z. S. (2015). Consumers' perceptions of organic food attributes and cognitive and affective attitudes as determinants of their purchase intentions toward organic food. Food Quality and Preference, 39, 259-267.

Lucas, M. R. V., Röhrich, K., Marreiros, C., Fragoso, R., Kabbert, R., Clara, A. M., ... \& Böhm, S. (2008). Quality, safety and consumer behaviour towards organic food in Germany and Portugal (No. 2008_05). University of Evora, CEFAGEUE (Portugal).

Lusk, J. L., \& Briggeman, B. C. (2009). Food values. American Journal of Agricultural Economics, 91(1), $184-196$.

Magnusson, M. K., Arvola, A., Hursti, U. K. K., Åberg, L., \& Sjödén, P. O. (2001). Attitudes towards organic foods among Swedish consumers. British Food Journal, 103(3), 209-227.

Meixner, O., Haas, R., Perevoshchikova, Y., \& Canavari, M. (2014). Consumer attitudes, knowledge, and behavior in the Russian market for organic food. International Journal on Food System Dynamics, 5(2), 110-120. 
Menapace, L., Colson, G., Grebitus, C., \& Facendola, M. (2011). Consumers' preferences for geographical origin labels: evidence from the Canadian olive oil market. European Review of Agricultural Economics, 38(2), 193-212.

Muhammad, S., Fathelrahman, E., \& Tasbih Ullah, R. U. (2016). The significance of consumer's awareness about organic food products in the United Arab Emirates. Sustainability, 8(9), 833.

Mohand, N. N., Hammoudi, A., Radjef, M. S., Hamza, O., \& Perito, M. A. (2017). How do food safety regulations influence market price? A theoretical analysis. British Food Journal.

Oroian, C. F., Safirescu, C. O., Harun, R., Chiciudean, G. O., Arion, F. H., Muresan, I. C., \& Bordeanu, B. M. (2017). Consumers' attitudes towards organic products and sustainable development: a case study of Romania. Sustainability, 9(9), 1559.

Padel, S., \& Foster, C. (2005). Exploring the gap between attitudes and behaviour: Understanding why consumers buy or do not buy organic food. British food journal.

Pearson, D., Henryks, J., Sultan, P., \& Anisimova, T. (2013). Organic food: Exploring purchase frequency to explain consumer behavior. Journal of Organic Systems, 8(2), 50-63.

Perito, M. A., Coderoni, S., \& Russo, C. (2020). Consumer attitudes towards local and organic food with upcycled ingredients: An italian case study for olive leaves. Foods, 9(9), 1325.

Perito, M. A., Sacchetti, G., Di Mattia, C. D., Chiodo, E., Pittia, P., Saguy, I. S., \& Cohen, E. (2019). Buy local! Familiarity and preferences for extra virgin olive oil of Italian consumers. Journal of Food Products Marketing, 25(4), $462-477$.

Peschel, A. O., \& Aschemann-Witzel, J. (2020). Sell more for less or less for more? The role of transparency in consumer response to upcycled food products. Journal of Cleaner Production, 273, 122884.

Ramesh, S. V., \& Divya, M. (2015). A study on consumers' awareness attitude and satisfaction towards select organic food products with reference to Coimbatore. International Journal of Interdisciplinary and Multidisciplinary Studies (IJIMS), 2(04), 81-84.

Russo, C., \& Simeone, M. (2017). The growing influence of social and digital media. British Food Journal.

Saba, A., \& Messina, F. (2003). Attitudes towards organic foods and risk/benefit perception associated with pesticides. Food Quality and Preference, 14(8), 637-645.

Sadati, S. A., Sadati, S. A., Fami, H. S., \& Del, P. T. T. (2010). Survey consumer attitude toward barriers of organic products (op) in Iran: A case study in Gorgan City. World Applied Sciences Journal, 8(11), 1298-1303.

Sangkumchaliang, P., \& Huang, W. C. (2012). Consumers' perceptions and attitudes of organic food products in Northern Thailand. International Food and Agribusiness Management Review, 15(1030-2016-82915), 87-102.

Schleenbecker, R., \& Hamm, U. (2013). Consumers' perception of organic product characteristics. A review. Appetite, 71, 420-429.

Steenhuis, I. H., Waterlander, W. E., \& De Mul, A. (2011). Consumer food choices: the role of price and pricing strategies. Public Health Nutrition, 14(12), 2220-2226.

Stolz, H., Stolze, M., Hamm, U., Janssen, M., \& Ruto, E. (2011). Consumer attitudes towards organic versus conventional food with specific quality attributes. NJAS-Wageningen Journal of Life Sciences, 58(3-4), 67-72.

Teng, C. C., \& Wang, Y. M. (2015). Decisional factors driving organic food consumption. British Food Journal, 117(3), 1066-1081

Toit, L., \& Crafford, S. (2003). Beliefs and purchasing practices of Cape Town consumers regarding organically produced food. Journal of Consumer Sciences, 31.

Ueasangkomsate, P., \& Santiteerakul, S. (2016). A study of consumers' attitudes and intention to buy organic foods for sustainability. Procedia Environmental Sciences, 34, 423-430.

Van der Lans, I. A., Van Ittersum, K., De Cicco, A., \& Loseby, M. (2001). The role of the region of origin and EU certificates of origin in consumer evaluation of food products. European Review of Agricultural Economics, 28(4), 451-477.

Van Huylenbroek, G., Mondelaers, K., Aertsens, J., Aertsens, J., Verbeke, W., Mondelaers, K., \& Van Huylenbroeck, G. (2009). Personal determinants of organic food consumption: a review. British Food Journal, 111(10).

Wee, C. S., Ariff, M. S. B. M., Zakuan, N., Tajudin, M. N. M., Ismail, K., \& Ishak, N. (2014). Consumers perception, purchase intention and actual purchase behavior of organic food products. Review of Integrative Business and Economics Research, 3(2), 378.

Wier, M., Jensen, K. O. D., Andersen, L. M., \& Millock, K. (2008). The character of demand in mature organic food markets: Great Britain and Denmark compared. Food Policy, 33(5), 406-421.

Xie, B., Wang, L., Yang, H., Wang, Y., \& Zhang, M. (2015). Consumer perceptions and attitudes of organic food products in Eastern China. British Food Journal, 117(3), 1105-1121.

Yadav, R., \& Pathak, G. S. (2016). Intention to purchase organic food among young consumers: Evidences from a developing nation. Appetite, 96, 122-128.

Zagata, L. (2012). Consumers' beliefs and behavioural intentions towards organic food. Evidence from the Czech Republic. Appetite, 59(1), 81-89.

Zander, K., \& Hamm, U. (2010). Consumer preferences for additional ethical attributes of organic food. Food quality and preference, 21(5), 495-503.

Zanoli, R., \& Naspetti, S. (2002). Consumer motivations in the purchase of organic food: A means-end approach. British Food Journal, 104(8), 643-653. 
(C) 2021 by the authors; licensee Growing Science, Canada. This is an open access article distributed under the terms and conditions of the Creative Commons Attribution (CC-BY) license (http://creativecommons.org/licenses/by/4.0/). 